facts which induced him to consider those layers at St. John's as belonging to the Lower Carboniferous. Therefore naturalists will scarcely agree that such a statement, made by a prominent and acknowledged authority, can be cancelled by a simple nega. tion not supported by facts. Till this is done in a reliable manner, those oldest insects will have to be considered as belonging to the Lower Carboniferous.

Cambridge, Mass., July 25

H. A. HAGEN

\section{The True Coefficient of Mortality}

THE very interesting and suggestive lecture of Alexander Buchan on "The Weather and Health of London" (NATURE, vol. xxiv. p. 143 et seq.) reminds me of the propriety of calling the attention of writers on "vital statistics" to a point in relation to the true method of discussing the mortuary data. The specific point to which attention is drawn is the necessity of estimating the relative tendency to special diseases by comparing the number of deaths from the given cause with the number of persons living at the ages embraced in the record; instead of making the comparison (as is usually done) with the total death from all causes, or with the total number living at all ages.

In like manner, in discussing the influence of age on the mortality from any given disease, it is very common to prepare tables of the number of deaths at each age, and in some instances these numbers have been assumed to represent the relative tendency to the disease at different ages. It is scarcely necessary to say that this is a very serious error, for it must be borne in mind that the number of persons living at different ages is very unequal. Indeed it is self-evident that the true coefficient of mortality for any given disease at any given age is expressed by the ratio of the number of deaths from the specified disease at the given age to the number of persons living at the same, age : or, as it may be otherwise indicated, the number of deaths from the given disease at the given age per 1000 persons living at the same irge.

In illustrating this point I shall select cancer, because, in relation to the influence of age, it furnishes an extreme case, and thus affords a glaring instance of the fallacy of taking any basis of comparison other than the number of persons living at each age. The mortuary records of the Department of Seine in France, during the eleven years, from 1830 to 1840 inclusive, furnish a total of 9118 deaths from cancer, 2163 males and 6955 females. The following table relating to the mean annual mortality from this disease among females will illustrate this point :-

\begin{tabular}{|c|c|c|c|c|}
\hline $\begin{array}{l}\text { Age. } \\
\text { Years. }\end{array}$ & $\begin{array}{l}\text { Number of } \\
\text { females living. }\end{array}$ & $\begin{array}{c}\text { Mean annual } \\
\text { deaths from } \\
\text { cancer among } \\
\text { females. }\end{array}$ & $\begin{array}{l}\text { Annual deaths } \\
\text { from cancer } \\
\text { in rooo } \\
\text { females } \\
\text { living at all } \\
\text { ages. }\end{array}$ & $\begin{array}{l}\text { Annual deaths } \\
\text { from cancer } \\
\text { in rooo } \\
\text { females } \\
\text { living at each } \\
\text { age. }\end{array}$ \\
\hline (1) & (2) & (3) & (4) & (5) \\
\hline 0 to 10 & I 39,840 & I 273 & - & 0.00910 \\
\hline 10 , 20 & I 15,269 & $1 \cdot 182$ & - & 0.01026 \\
\hline $20 ", 30$ & 104,342 & $15 \cdot 364$ & 0.04196 & 0.14725 \\
\hline 30,40 & 73,203 & 74.727 & 0.20409 & $1.0208 \mathrm{I}$ \\
\hline $40, \quad 50$ & 54,124 & 148.727 & 0.40619 & $2 \cdot 74788$ \\
\hline $50 ", 60$ & 36,800 & 147.273 & $0.4022 \mathrm{I}$ & $4^{\circ} 00198$ \\
\hline $60,7,70$ & 25,703 & 133.545 & 0.36472 & $5 \cdot 19564$ \\
\hline 70,180 & 12,852 & 83.364 & 0.22767 & 6.48659 \\
\hline $80, " 90$ & 3680 & 24.818 & 0.06778 & 6.74408 \\
\hline 90,100 & 340 & $2 \cdot 000$ & 0.00546 & 5.88769 \\
\hline All ages. & $5^{66,},{ }_{53}$ & $632 \cdot 273$ & - & I'I 1679 \\
\hline
\end{tabular}

The foregoing table demonstrates the inaccuracy of the popular impression that the tendency to cancer attains its maximum between the ages of 35 and 50 years. The numbers in columns (3) and (4) might seem to support such an opinion; but, as we have seen, those in column (5) are evidently the true indices of the tendency to this disease at different ages; and it will be observed that the mortality goes on steadily augmenting with each succeeding decade of age up to 90 years. The fact likely to be most strongly impressed on the reader by the numbers in column (5) is the remarkable regularity of increase of the co- efficient of mortality for cancer with advancing life among females after the age of 25 or 30 years. Between the ages of 25 and 75 the mortality increases nearly in arithmetical progression as the age advances in arithmetical progression, the average increment being about $I \cdot 30$ per I0oo living at each age for each decade. Assuming this to be the law of mortality from cancer among females, it admits of very simple mathematical expression. Thus, let
$A=$ the age at which liability to cancer begins.
$\mathrm{A}^{\prime}=$ any age greater than $\mathrm{A}$.
$\mathrm{C}=$ constant coefficient, variable according to country, state of civilisation, \&c.

Then we have-Annual mortality per rooo living at age $\mathrm{A}^{\prime}=\mathrm{C}$ $\left(A^{\prime}-A\right)$.

In our table representing the mortality from cancer in the department of the Seine from 1830 to 1840 inclusive, the value of $\mathrm{A}$ may be taken $=25$, and $\mathrm{C}=0^{\circ} \mathrm{I} 3$; hence we have-Annual mortality per rooo living at age $\mathrm{A}^{\prime}=0^{\circ} \mathrm{I}_{3}\left(\mathrm{~A}^{\prime}-25\right)$. Thus by the formula the mortality at $55=3.90$, and column (5) gives $4^{\circ} 00$ between 50 and 60 ; at 75 , formula $=6.50$; table $=6.49$ between 70 and 80 .

The mortality from cancer seems to be vastly smaller in England than it is in France, so that a less value must be given to the constant $\mathrm{C}$. The foregoing formula represents the law of increasing mortality with advancing life in the simplest form, as a function of the age. This extreme simplicity is probably unique in the case of cancer, and seems to indicate that age is so far the controlling element in the development of this disease as to overpower all other causes. In the case of other diseases we cannot expect to escape the necessity of employing those exponential functions in investigating their laws of mortality, which are essential when a multiplicity of causes are in operation.

Many years ago the attention of the medical profession in this country was called to the fact that the available mortuary data were not discussed in a manner which revealed the true value of the facts contained in the numbers. ${ }^{1}$ But there is reason to believe that Prof. Francis A. Walker, the inteliigent superintendent of the census of the United States for 1880, will not overlook this point when he comes to the discussion of the mortuary statistic 3 which have been collected.

Berkeley, California, July 7

John Le Conte

[Mr. Le Conte does not appear to have apprebended the point discussed in the lecture on "The Weather and Health of London"-that point in no part of the inquiry being the tendency to the disease at differest ages, but the manner of the distribution of deaths in the case of each disease through the weeks of the year, with the view of arriving at some knowledge of the influence of season in determining that distribution. Only in one case, viz., in discussing the rates of the mortality from diarrhœa in several large towns, was a reference to population required, and in that case the curves were drawn, showing the weekly rate of mortality per 1000 of the population of the respective towns.-ALEXANDER BUCHAN.]

\section{Bisected Humble Bees}

I TOO have frequently observed humble bees lying dead or stupefied under lime-trees, sun-flowers, and some other plants, and once I saw a Staphylinus, commonly known as Black Cock-tail, or Devil's Coach-horse, nip a humble bee in two, and on pas-ing that way later I found that it bad cleared out the honey-bag and left the two halves of the bee on the path, as described by your correspondent. I have known boys catch humble bees and eat the honey in them; and probably many other animals have learned how to get at the sweet drop.

Trinity College, Cambridge

THOS. MCK. HUGHES

A $T$ your request for information on the above I beg to say that I have observed both the flycatchers alluded to by your correspondent, and also the little blue tit (Parus corulea) attack the humble bees in the manner described, to extract the honeybag. This attacking the bees is not, so far as my experience goes, a general characteristic of these birds, and what should lead them to it occasionally I cannot ascertain.

Exeter, August is

EDWARD PARFITT

I Vide papers by the writer, entitled "Statistical Researches on Cancer,' Southern Med. and Surg. Yourn., new series, vol. ii. pp. $257-293$, May' Southern Med. and Surg. Fourn., new series, "Laws of Mortality from 1846. Also "Western Lancet, vol. i. pp. x76-190, March, 1872 (San Francisco). 